\title{
STRATEGI PENINGKATAN IN PUT DAN MUTU LULUSAN FAKULTAS DAKWAH DAN ILMU KOMUNIKASI UIN MATARAM
}

\author{
Ahyar \\ Universitas Islam Negeri Mataram \\ e-mail: hyfa_loteng@yahoo.co.id
}

\begin{abstract}
Improving the quality of inputs and graduates of Higher Education is a basic program based on the program through an integrated approach starting from input-process, the output out to come out. The PMI Department is one of the majors at FDIK, Mataram UIN which continues to improve even though since its opening in 2007 until 2017 from the inside side it still experiences a less encouraging trend. Therefore, through this research, we want to find the image of the community towards its existence, the direction of the policy and the strategy of increasing the graduates' input. This study uses survey research, where researchers try to find people's perceptions through closed questions. The method of collecting data through questionnaires, and coupled with interviews, observation and documentation. While data analysis uses an interactive model analysis through data collection, data reduction and verification or conclusion. The credibility of data is through an extension of the time of research and triangulation. The results of the study found that a) the perception or image of the community about the existence of the FDI PMI Department Mataram UIN is still formalist and normative meaning that it only sees things that are not substantive, b) Policy directions through two models, namely the direction of academic and sociological policies, and c) improvement strategies through internal academic reinforcement and external reinforcement (partnership).
\end{abstract}

\section{Key Words:}

Input Strategy, Graduate Quality, Community Perception 


\begin{abstract}
Abstrak
Peningkatan mutu input dan lulusan Perguruan Tinggi merupakan program dasar based program melalui pendekatan secara terintegrasi mulai dari input-proses, out put sampai ke out come. Adalah Jurusan PMI merupakan salah satu jurusan di FDIK UIN Mataram yang terus berbenah kendati sejak dibuka tahun 2007 sampai saat 2017 dari sisi in put masih mengalami trend yang kurang menggembirakan. Oleh karena itu, melalui penelitian ini ingin menemukan imej masyarakat terhadap keberadaannya, arah kebijakan dan strategi peningkatan in put lulusannya. Penelitian ini menggunakan penelitian survey, di mana peneliti berusaha untuk menemukan persepsi masyarakat melalui pertanyaan tertutup. Metode pengumpulan data melalui angket, dan ditambah dengan wawancara, observasi dan dokumentasi. Sementara analisis data mengunakan analisis model interaktif melalui pengumpulan data, reduksi data serta verifikasi atau penarikan kesimpulan. Adapun kredibiltas data melalui perpanjangan waktu penelitian dan triangulasi. Hasil penelitian menemukan a) persepsi atau imej masyarakat tentang keberadaan Jurusan PMI FDIK UIN Mataram masih bersifat formalis dan normatif artinya hanya melihat dari hal-hal yang nampak bukan yang subtantif, b) Arah kebijakan melalui dua model yakni arah kebijakan akademis dan sosiologis, dan c) strategi peningkatannya melalui penguatan internal akademik dan penguatan eksternal (kemitraan).
\end{abstract}

\title{
Kata Kunci:
}

Strategi Input, Mutu Lulusan, Persepsi Masyarakat 


\section{A. Pendahuluan}

Fakultas Dakwah dan Ilmu Komunikasi (FDIK) sebagai salah satu fakultas di UIN Mataram terus bertekad berbenah dalam rangka menjawab tantangan dan tuntutan kebutuhan masyarakat. Untuk menjawab tantangan tersebut, FDK telah berusaha melakukan langkah-langkah terobosan strategis menuju pengembangan dan perubahan ke arah kemajuan dan perubahan positif dengan didukung dengan komitmen seluruh civitas akademikanya.

Agar cita-cita tersebut dapat terealisasi, perubahan dan pengembangan tersebut, FDIK UIN Mataram telah menyusun rencana strategis secara matang, sistematis, dan integral dalam kurun waktu tertentu yang tertuang dalam Rencana Induk Pengembangan (RIP) FDIK UIN Mataram. Rencana strategis (RENSTRA) ini menggambarkan sasaran, strategi, prioritas dan tujuan yang ingin dicapai serta program-program yang ingin dilaksanakan dalam kurun waktu lima tahun mendatang. Renstra ini menjadi pedoman bagi semua pihak yang terlibat dalam pengembangan lembaga ini. Sebagai sebuah rencana strategis, rencana pengembangan ini juga memuat kerangka filosofis, dan langkah-langkah operasionalnya.

Dari sisi pengembangan kelembagaan misalnya, enam tahun lalu, tepatnya tahun 2011 , seiring dengan kebutuhan dan peluang yang ada, FDIK UIN Mataram membuka jurusan BKI, jurusan BKI telah mendapat respon yang sangat positif dengan ditandai dengan banyaknya calon mahasiswa yang mendaftar. Minat masyarakat untuk memasukkan putra-putrinya dari berbagai daerah patut menjadi apreasiasi. Kemudian disusul empat tahun kemudian yakni tahun 2014, FDIK UIN 
Mataram lagi membuka jurusan Sosiologi Agama (SA), jurusan SA juga mendapat respon yang positif dari masyarakat dengan banyaknya calon mahasiswa yang mendaftar dari berbagai daerah. Inilah realitas yang harus disyukuri di satu sisi, namun di sisi lain, FDIK UIN Mataram masih mendapat tugas berat dan menjadi perhatian serius civitas akademika FDIK UIN Mataram dengan adanya jurusan yang minim peminat kendati berbagai terobosan pernah dilakukan.

Adalah jurusan $\mathrm{PMI}^{51}$ merupakan jurusan yang masih minim peminat, padahal jurusan PMI cukup lama setelah dibuka sejak tahun 2007. Jika melihat data statistik lima tahun terakhir mahasiswa PMI menunjukkan angka yang pluktuatif dan belum pernah mencapai 80 orang setiap angkatan dan bahkan mereka yang masuk adalah mereka yang tidak diterima di Fakultas Tarbiyah dan Syariah. Sebagai gambaran berikut ini disajikan grafik perkembangan data penerimaan mahasiswa jurusan PMI lima tahun terakhir.

Tabel. 1

Grafik Perkembangan Data Penerimaan Mahasiswa Jurusan PMI FDIK UIN Mataram

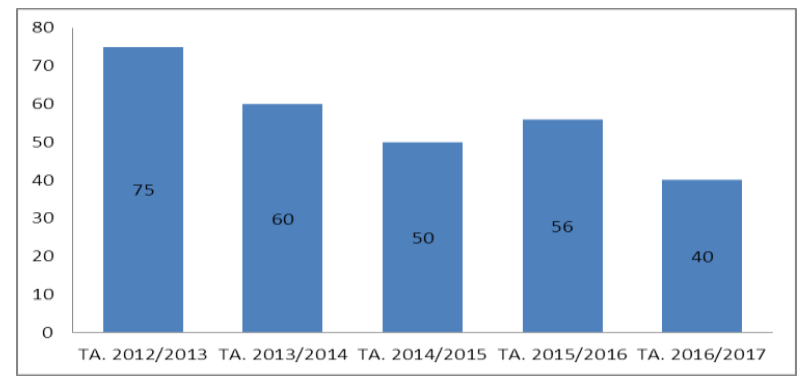

51 Jurusan Pengembangan Masyarakat Islam (PMI) Fakultas Dakwah dan Komunikasi IAIN Mataram beroperasi berdasarkan SK Dirjen Pembinaan Kelembagaan Islam Departemen Agama RI Nomor: E/123/2001 kemudian Surat Keputusan Perpanjangan Izin Penyelenggaraan dari Direktur Jendral Pendidikan Tinggi Islam Nomor: Dj. l/ 221 / 2007 tanggal 29 Mei 2007. Dan dengan usaha keras untuk meningkatkan status jurusan maka jurusan PMI kemudian terakreditasi oleh Badan Akreditasi Nasional-Perguruan Tinggi (BAN-PT) nomor: 002/BAN-PT/Ak.XIII/S1/IV/2010, tertanggal 30 April 2010 dengan nilai B. Status akreditasi ini berlaku selama 5 (Lima) tahun (2010-2015). Buku Pendoman Akademik FDK IAIN Mataram Tahun 2015, 46. 
Berdasarkan data perkembangan setiap tahun yang cenderung menurun akan berimplikasi pada kualitas in put yang relatif di bawah standar kendati ada yang cukup menonjol namun jumlahnya sangat sedikit. Ini artinya ada sesuatu yang harus ditelaah secara mendalam, banyak asumsi yang berkembang di kalangan dosen, asumsi-asumsi tersebut seperti, Jurusan PMI kurang layak dijual karena namanya cukup asing didengar di lingkungan masyarakat, orientasi pasar kerja yang relatif masih sedikit, jurusan yang kurang prosfektif di pasar kerja dan bahkan secara sadar atau tidak kalimat yang sering muncul, jurusan PMI adalah jurusan yang langka peminat. Kendati out put PMI sudah mendapat pengakuan dengan telah diterima beberapa lulusannya di beberapa instansi pemerintah dan non pemerintah.

Kendati demikian, FDIK UIN Mataram telah melakukan berbagai terobosan baik melalui patnership dengan lembaga lain, sosialisasi secara sporadis bahkan turun gunung, namun kondisi ini belum mampu mendongkrak animo masyarakat untuk masuk ke Jurusan PMI. Sementara, Jurusan KPI, BKI dan SA telah menunjukkan trend positif baik dari sisi jumlah maupun kualitas input, sehingga tiga jurusan ini telah memberikan implikasi positif bagi perkembangan FDIK UIN Mataram saat ini. Jumlah mahasiswa menunjukkan grafik peningkatan secara signifikan dari tiga jurusan ini. Menurut hemat peneliti disinilah letaknya urgensi penelitian ini dilakukan, tidak sekedar mendeskripsikan persoalan-persoalan yang dihadapi namun dapat menganalisis sumber-sumber yang dapat memberikan implikasi positif, khususnya pada jurusan PMI. 


\section{B. Kajian Teoritik}

\section{Startegi Peningkatan In put}

Kata strategi merujuk pada sebuah rencana, pola yang akan dilakukan dalam mencapai tujuan. Strategi dapat diterjemahkan wilayah kompetitif perusahaan, Strategy as a definition of the competitive domain of the firm. Strategi dimaknai sebagai strategi membangun tujuan organisasi dalam pola tujuan jangka panjang, tindakan program, dan prioritas alokasi sumber, (Strategy as a means of establishment the organizational purpose in terms of its long-term objective, action programs, and resource allocation priorities). ${ }^{52}$ Beberapa makna ini menunjukkan adanya upaya untuk melalukan tindakan dengan model-model tertentu dengan menggunakan sumber-sumber yang dimiliki untuk mencapai tujuan.

Adapun strategi peningkatan in put pada kajian ini lebih pada konsep strategi pemasaran barang atau jasa. Kata pemasaran identik dengan sesuatu yang bersifat fisikal atau material dan barang jadi, sementara pemasaran dalam peningkatan in put yang dimaksud adalah lebih menitikberatkan kepada pemasaran jasa. Karena jasa sesuatu yang abstrak maka diperlukan strategi yang memiliki daya ungkit sehingga apa yang dipasarkan mendapat respon dari masyarakat dengan baik. Salah satu konsep pemasaran jasa merujuk pada konsep Total Quality Management (TQM).

52 Michael E. Porter, Competitive Strategy: Techniques for Analyzing Industries an Competitors (New York: The Free Press, 1980), 2-3. 
Total Quality Management telah menghadirkan wajah baru dalam perspektif manajemen. Berfikir mutu tidak semata-mata berpikir tentang satu komponen melainkan berpikir sistem dan menyeluruh. Berfikir secara total dalam konteks manajemen. TQM merupakan filosofi dan metodologi yang membantu organisasi termasuk dunia PT yang menyediakan jasa pendidikan untuk mengelola peruabahan. Esensi TQM adalah perubahan budaya (cultutre change). ${ }^{53}$ Bill Greech dalam bukunya "Lima Pilar Manajemen Mutu Terpadu (Total Quality Management) memberikan penjelasan bahwa mutu itu tidak rumit bila dijalankan dengan benar. Adapun lima pilar yang dimaksud adalah produk, proses, organisasi, leadership dan komitmen. Produk adalah titik fokus untuk tujuan dan pencapaian orgnisasi, mutu dalam produk tidak mungkin dicapai tanpa mutu dalam proses. Mutu dalam proses tidak mungkin dicapai tanpa organisasi yang tepat. Organisasi yang tepat tidak ada artinya tanpa kepemimpinan yang memadai. Komitmen yang kuat, dari bawah ke atas merupakan dukungan pilar untuk pilar yang lain. Setiap pilar tergantung pada empat pilar yang lain, dan bila ada salah satu yang lemah, semua akan lemah. ${ }^{54}$

Berbicara produk, Jurusan PMI sesuai dengan profil lulusan ingin melahirkan sarjana yang dapat berkiprah dalam berbagai Profesi, baik sebagai PNS (TNI/POLRI, KEMENAG, KEMENSOS, PEMDA, BKKBN, DIKPORA, KEMENLU, KPID, KOMINFO, Badan Narkotika Nasional) maupun sektor

${ }^{53}$ Dorothea Wahyu Ariani, TQM dalam Sektor Pendidikan, Jurnal Modus, FE-UAJY, 1998, 12

54 Bill Greech, Lima Pilar Manajemen Mutu Terpadu (Total Quality Management, Jakarta: Binarupa Aksara, 1996), 521. 
swasta seperti Bank Syariah Mandiri, Peneliti, Pekerja Sosial, dan Fasilitator Pengembang Masyarakat, Guru, dan Dosen. Tawaran produk ini tidak mungkin dicapai tanpa mutu dalam proses. Marketing produk tentu harus diimbangi dengan mutu dalam proses.

Dalam menjalankan "marketing", dan memperkuat emej masyarakat ada banyak cara yang dilakukan dalam pemasaran produk jasa, berikut adalah di antaranya : pertama; menggunakan media sosial/internet marketing, semua orang pasti sudah tidak asing lagi dengan WhatsApp, BBM, facebook, twitter, dan media social semacamnya. Kedua, testimoni, sebagaimana hasil penelitian dari Abdullah AL-Mutairi \& Muna Saeid, meneliti tentang Factors Affecting Students' Choice for MBA Program in Kuwait Universitie ${ }^{55}$ menunjukkan program alumni yang menjadi variabel paling dominan ketika para calon ditanya mengenai dari mana sumber informasi mereka peroleh tentang program MBA, sementara variabel lain masih lebih sedikit pengaruhnya jika dibandingkan dengan variabel program alumni, seperti variabel campus visit, friends' suggestions, University websites, Educational seminars/ fairs, Family's advice, Magazine and journal, Posters in Public places (Avenues) Advertisement in TV, Advertisement in Radio Posters on public transport (buses). Ini artinya, marketing jasa melalui testimoni dari para alumni menjadi faktor kunci keberhasilan pemasaran produk jasa bagi PT.

Selanjutnya, mutu dalam proses tidak mungkin dicapai tanpa organisasi yang tepat. Organisasi yang tepat merupakan syarat proses pelayanan

\footnotetext{
${ }^{55}$ Ibid, 125
} 
akademik yang baik. Organisasi yang tepat lebih merujuk pada model organisasi yang dapat menjalankan aktivitas organisasi tanpa selalu melihat apakah organisasi tersebut besar atau kecil. Demikian juga, organisasi yang tepat harus dikawal dengan kepemimpinan yang memadai pula. Tidak ada satu teori kepemimpinan yang memadai dalam menjawab satu situasi yang diperlukan, teori kepemimpinan dibutuhkan dan diperlukan ketika dapat menjawab persoalan dan tantangan organisasi. Di sinilah letak atau posisi urgensinya teori tanpa membatasi dengan teori yang ada. Keempat pilar tersebut harus ada komitmen. Komitmen yang kuat mulai dari bawah ke atas merupakan dukungan pilar untuk pilar yang lain. Lima pilar tersebut merupakan satu lingkaran yang saling terikat pada empat pilar yang lain, dan bila ada salah satu yang lemah, maka semua pilar akan lemah.

\section{Startegi Peningkatan OKualitas ut put}

Dalam konsep TQM ada tiga prinsip mutu dalam meningkatkan kualitas out put yang dikembangkan yaitu : pertama; fokus pada pelanggan (customer focus); Mutu berdasarkan pada konsep bahwa setiap orang mempunyai pelanggan dan bahwa kebutuhan dan harapan pelanggan harus dipenuhi setiap saat kalau organisasi secara keseluruhan bermaksud memenuhi kebutuhan pelanggan eksternal (pembeli). ${ }^{56}$ Karena pendidikan memproduksi jasa maka bagaimana upaya Perguruan Tinggi sebagai lembaga pendidikan dapat memastikan bahwa konsep mutu harus diarahkan kepada pelanggan

\footnotetext{
${ }^{56}$ IGP Kawiana, Manajemen Mutu Terpadu serta Kaitannya Dengan Perilaku Produktif Karyawan, Diakses 21 Februari 2017 dari https://geogle.com
} 
yakni mahasiswa dan stakeholdernya. Oleh karena itu, TQM bukan pengendalian mutu (quality control) yang merupakan pengendalian mutu setelah proses produksi, namun TQM selalu pada kepuasan pelanggan (customer satisfaction) dan melakukan pengendalian mutu sejak awal.

Kedua: Perbaikan proses; (Countinous improvement). Konsep perbaikan terus menerus dibentuk berdasarkan pada premisi suatu seri (urutan) langkahlangkah kegiatan yang berkaitan dengan menghasilkan output seperti produk berupa barang dan jasa. Perhatian secara terus menerus bagi setiap langkah dalam proses kerja sangat penting untuk mengurangi keragaman dari output dan memperbaiki keandalan. Tujuan pertama perbaikan secara terus menerus ialah proses yang handal, dalam arti bahwa dapat diproduksi yang diinginkan setiap saat tanpa variasi yang diminimumkan. Apabila keragaman telah dibuat minimum dan hasilnya belum dapat diterima maka tujuan kedua dari perbaikan proses ialah merancang kembali proses tersebut untuk memproduksi output yang lebih dapat memenuhi kebutuhan pelanggan, agar memenuhi kepuasan pelanggan. Namun apa yang dikatakan Dorethea ${ }^{57}$ ada benarnya, masih banyak lembaga pendidikan yang tidak berorientasi pada keuntungan (qualitas) dan kepuasan pelanggan. Kondisi inilah yang menyebabkan mereka tidak dengan sepenuh hati bekerja pada lembaga pendidikan tersebut, karena rajin atau malas, mereka akan mendapat nilai yang sama sepanjang waktu. Dan ketiga; Keterlibatan total (total involvement), pendekatan ini dimulai dengan kepemimpinan manajemen senior yang aktif dan mencakup usaha yang

${ }^{57}$ Dorothea Wahyu Ariani, h. 13. 
memanfaatkan bakat semua karyawan dalam suatu organisasi untuk mencapai suatu keunggulan kompetitif (competitive advantage) di pasar yang dimasuki. Pegawai pada semua tingkatan diberi wewenang/kuasa untuk memperbaiki output melalui kerjasama dalam struktur kerja baru yang luwes (fleksibel) untuk memecahkan persoalan, memperbaiki proses dan memuaskan pelanggan. Mahasiswa juga dilibatkan dari waktu ke waktu menjadi mitra melalui kerjasama dengan para dosen dan pegawai yang telah diberi wewenang/kuasa yang dapat menguntungkan organisasi. Pada waktu yang sama keterlibatan pimpinan bekerjasama dengan pegawai yang telah diberi kuasa tersebut dapat berialan dengan baik. ${ }^{58}$

Dengan demikian, total involvement merupakan semua upaya untuk mengoptimalkan semua kemampuan tenaga pendidik dan tenaga kependidikan sehingga organisasi memperoleh keuntungan yang kompetitif. Pada dasarnya total imvolvement terdiri atas dua elemen utama yaitu: (1) kepemimpinan (leadership), dan (2) pemberdayaan pegawai (empowered work force).

Kathleen $d k k,{ }^{59}$ berpendapat bahwa yang paling penting untuk melaksanakan TQM dalam lembaga pendidikan (PT) antara lain: pertama; tanggung jawab dan dukungan (commitment) pimpinan lembaga yang dikomunikasikan kepada semua pihak, kedua; pendidikan dan pelatihan bukan hanya ditujukan untuk pegawai akademik dan non akademik tetapi pelatihan untuk kesiapan dalam menghadapi perubahan dan perbaikan. Ketiga;

\footnotetext{
${ }^{58}$ IGP Kawiana, Manajemen Mutu Terpadu serta Kaitannya Dengan Perilaku Produktif Karyawan, 2009. Diakses 21 Februari 2017 dari https://geogle.com

59 Dorothea Wahyu Ariani..., 14.
} 
penerapan dan praktek (application and practice). Tanpa pelaksanaan dan praktek TQM hanya slogan.

Salah satu strategi peningkatan kualitas out put dalam menerapkan konsep TQM di lembaga pendidikan perlu dibentuk tim teaching yang tugasnya antara lain; memperlakukan mahasiswa sebagai pelanggan, memberdayakan para mahasiswa dengan memberikan kebebasan untuk memilih bidang-bidang yang akan diteliti, mengembangkan lingkungan yang mendukung kerja tim, mengikat para mahasiswa dalam proses perbaikan secara terus menerus, dan menunjukkan gaya kepemimpinan di kelas dengan mutu proses pengajaran yang baik.

Oleh karena itu, tiga konsep TQM tersebut, kiranya lembaga memiliki komitmen kepada pelanggan sebagai fokus (custemer focus); perbaikan secara terus-menerus dan berkesinambungan (continuous improvement); kerja tim (team work); dan perubahan budaya(Culture change).

\section{Temuan dan Pembahasan}

\section{Analisis Imej Masyarakat (Stakeholder) Tentang Keberadaan Jurusan PMI} FDIK IAIN Mataram

Berdasarkan hasil survey lapangan menunjukkan bahwa imej atau pandangan masyarakat (sekolah) tentang keberadaan Jurusan PMI FDIK UIN Mataram menunjukkan trend yang cukup signifikan. Dari dua lokasi yang menjadi tempat survey, yakni di Madrasah Aliyah Darul Muhajirin Praya maupun di MA Ponpes Islahuddin Kediri, telah memberikan gambaran 
bahwa sesungguhnya Jurusan PMI FDIK UIN Mataram telah dikenal oleh masyarakat ponpes. Hal ini tidak terlepas dari peran serta pihak lembaga dalam mensosialisasikan Jurusan PMI FDIK UIN Mataram di masyarakat. Kendati ada beberapa responden yang sangat asing terhadap Jurusan PMI FDIK UIN Mataram.

Sementara informasi tentang Jurusan PMI FDIK UIN Mataram, respoden mendapat informasi dari berbagai macam sumber mulai dari teman, alumni, keluarga, sekolah, media cetak dan media elektronik. Tetapi dari sekian banyak sumber informasi, ternyata madrasah paling dominan memberikan informasi tentang keberadaan Jurusan PMI FDIK UIN Mataram kepada responden. Ini artinya, madrasah masih dipandang menjadi instrumen penting dalam melakukan sosialisasi keberadaan Jurusan PMI FDIK UIN Mataram kepada masyarakat. Yakni 90 persen responden mengaku mengetahui informasi tentang Jurusan PMI FDIK UIN Mataram melalui Sekolah.

Jurusan PMI FDIK UIN Mataram masih dipandang oleh responden masih miskin informasi tentang arah dan out put ke mana Jurusan PMI FDIK UIN Mataram. Terbukti 85 persen responden mengatakan masih blame atau buta tentang Jurusan PMI FDIK UIN Mataram. Responden kebanyakan tidak mengetahui fungsi dari keberadaan Jurusan PMI Fakultas Dakwah dan Komuikasi UIN Mataram . Kendati pihak Jurusan PMI FDIK UIN Mataram telah memfomulasikan keberadaan jurusan tersebut sebagai lulusan yang expert atau ahli dalam bidangnya. 
Yang menarik lagi, 87 persen responden mengatakan bahwa pilihan terhadap Jurusan PMI FDIK UIN Mataram karena dia tahu dan bahkan segi nama jurusan, 75 responden mengatakan tidak asing. Ini artinya ada sesuatu yang harus diperbaiki. Keberadaan Jurusan PMI FDIK UIN Mataram sebenarnya tidak amat asing di masyarakat hanya saja diperlukan lebih banyak terobosan-terobosan, misalnya ada keringanan-keringanan kebijakan lembaga.

Ketertarikan responden terhadap Jurusan PMI FDIK UIN Mataram memiliki alasan yang beragam. ada yang tertarik karena faktor nama, ada yang tertarik karena menjanjikan untuk lapangan pekerjaan, dan ada juga yang masih tidak mengetahui. 75 persen responden mengatakan Jurusan PMI FDIK UIN Mataram tidak tahu dan selebihnya karena faktor lain seperti mampu menjanjikan lapangan pekerjaan dan faktor nama jurusan. Hasil ini menunjukkan adanya fenomena sikap masyarakat yang masih berpandangan bahwa Jurusan PMI belum menjanikan dalam konteks kerja. Menurut hemat peneliti tampilan karakteristik personal mahasiswa PMI inilah menjadi kata kunci. Seperti apa gambaran personality skill, carier skill, social skill, dan humanities skill. Sehingga Muchammadun ${ }^{60}$ dalam artikelnya juga memberikan penekanan pada perlunya pemetaan karier lulusan PMI harus jelas. Bagaimana masyarakat yakin atas keterserapan lulusan di dunia kerja dan recruiters' reviews atas lulusannya. Bagaimana merubah Jurusan PMI

\footnotetext{
${ }^{60}$ Muchammadun, Transformasi IAIN ke UIN: Tinjauan Psikologi Sosial pada Jurusan PMI FDK IAIN Mataram, Jurnal Tasammuh, Volume 12, Nomor 1, Desember 2014.ISSN 1829-6-6483, 85
} 
dari religious butterfly ke religious and intellectual social graduate. Bagaimana merubah mind set masyarakat bahwa Jurusan PMI tidak sematamata terkesan mencetak ahli agama dan dai namun memiliki kemampuan atau kompetensi agama dan intelektual. Hasil penelitian Ming menemukan bahwa intres mahasiswa lebih dipengaruhi oleh lokasi kampus, program akademik, reputasi perguruan tinggi, fasilitas pendidikan, biaya, peluang pekerjaan, periklanan dan kunjungan kampus. Hasil penelitian ini jika ditelaah secara cermat maka ada variabel yang lebih dominan tidak hanya sekedar alasan yang nampak tangible seperti, lokasi kampus, fasilitas pendidikan, biaya, periklanan dan kunjungan kampus melainkan ada variabel yang lebih dominan seperti adanya program akademik, reputasi perguruan tinggi, dan peluang pekerjaan.

Dari angket naratif yang disebarkan telah mencerminkan bahwa keberadaan Jurusan PMI FDIK UIN Mataram tentu tidak semua responden mengetahuinya. Berdasarkan hasil jawaban naratif responden mengatakan responden, ada yang tidak pernah mendengar nama Jurusan PMI, responden menaruh harapan terhadap Jurusan PMI agar jurusan tersebut lebih dikenal dengan melakukan tindakan-tindakan seperti lebih sering turun ke lapangan, harus banyak publikasi lewat media cetak dan elektronik, dan harus sering membuat program untuk sekolah/masyarakat.

Adapun mengenai nama Jurusan PMI FDIK UIN Mataram bagi sebagian responden lebih baik berganti nama, bahkan ada yang sangat setuju jika PMI berganti nama kendati responden tidak mengemukakan alasannya. Ini 
artinya, Jurusan PMI masih dipandang sebagai jurusan yang belum seksi di masyarakat. Bahkan mereka yang masuk ke Jurusan PMI FDIK UIN Mataram yaitu lebih banyak yang yang ikut teman, dan karena dorongan keluarga. Sementara responden menjawab alasan memilih masuk Fakultas Syariah dan Ekonomi Islam dan Fakultas Tarbiyah dan Keguruan lebih banyak menjawab karena sesuai bakat.

Berdasarkan hasil pandangan responden tentu harus disikapi dengan arif, inilah fakta yang berkembang di lapangan. Kerja besar fakultas untuk mempertahankan PMI sebagai salah satu jurusan di FDIK UIN Mataram menjadi lebih serius menjadi kata kunci tanpa menafikan keberadaan jurusan-jurusan lain yang ada di lingkungan FDIK UIN Mataram. Meminjam temuan Muchammadun ${ }^{61}$ menekankan bahwa ada dua factor penentu untuk bercermin, yakni apakah sosialisasi peran FDIK dan jurusan PMI sudah berjalan baik dan berkelanjutan, dan apakah proses KBM di Jurusan PMI sudah mengacu pada pemerolehan kompetensi analitik dan keterampilan fasilitasi dengan didukung sejumlah perangkat SDM dan dukungan fasilitas.

\section{Analisis Arah Kebijakan Dalam Merubah Paradigma Jurusan PMI Supaya}

\section{Lebih Prosfektif Dan Marketable}

Arah kebijakan akademik Jurusan PMI sampai penelitian ini dilakukan belum ada arah kebijakan yang startegis. Namun setidak-tidaknya telah muncul beberapa ide strategis seperti perubahan nama Jurusan sebagai

\footnotetext{
${ }^{61} \mathrm{lbid}, 94$
} 
langkah antisitipatif. Sebab trend empat tahun terkhir ini input mahasiswa tidak bertambah. Ini artinya ada sesuatu yang menjadi menyebabnya. Untuk mencari menyebabnya perlu diskusi intens dan serius. Dari beberapa informan lebih menekankan pada interaksi komunikasi antara stakeholder dengan lembaga. Sebagai jurusan langka peminat dibutuhkan butuh model lain dalam mengembangkan jurusan ini. Sepertinya perlu belajar brainstorming ke Jurusan yang sama di PTKIN dan PTU yang lain atau Pihak jurusan perlu memanfaatkan moment asosiasi jurusan social work sebagai basis mengurai dan memberi solusi. Begitu juga perlunya penajaman paradigma jurusan atau merevitalisasi jurusan PMI ke Jurusan Social Worker. Jurusan PMI sebagaimana nomer klaturnya tetap dipertahankan namun perlu dirubah dari sisi content kosentrasinya sembari dengan terus melibatkan stakeholder yang ada dan lembaga mitra yang sejalan dengan arah kebijakan kurikulum PMI.

Model UIN Syarif Hidayatullah dan UIN Sunan Ampel Surabaya perlu dikaji karena di dua PT ini telah mengembangkan jurusan melalui penataan manajemen prodi. Misalnya, PMI sebagai jurusannya dan membawahi beberapa Program Studi. Sehingga PMI tetap menjadi nama jurusan dan membawahi beberapa program studi sebagai bidang peminatan atau kosentrasi.

Sejauh pengamatan peneliti, arah kebijakan akademis masih berada pada posisi menjalankan portopolio yang sudah ada kendati sudah ada inovasi-inovasi pengembangan, seperti model pengembangan praktikum 
yang berbasis pengalaman lapangan, adanya penguatan laboratorium PMI dengan programnya, serta memperkuat program Himpunan Mahasiswa Jurusan (HMJ) PMI.

Arah kebijakan yang lain, seperti penguatan struktur kurikulum. Berdasarkan temuan lapangan menunjukkan bahwa, Jurusan PMI sebagaimana jurusan yang lain, telah melakukan pembenahan kurikulum ke kurikulum yang berbasis KKNI. Tentu ini merupakan peluang dan sekaligus tantangan. Logika akademiknya adalah bagaimana memformulasikan kurikulum $\mathrm{KKNI}$ ini semakin dapat menarik dan merangsang mahasiswa untuk menekuni bidangnya sebagai pilihan utama. Semakin jelas dalam memformulasikan kurikulumnya akan semakin menjadi daya saing jurusan PMI dengan jurusan lain. Kurikulum yang berbasis vocational program menjadi instrumen penting dalam membangun kondisi kurikulum yang marketable.

Di sisi lain Jurusan PMI ini perlu didukung arah kebijakan yang partisipatif. Misalnya, sebenarnya tidak begitu urgen namun setidak-tidaknya dapat menaikkan grade peminat seperti adanya program beasiswa penuh kepada mahasiswa PMI quotanya lebih banyak ketimbang jurusan lain. Kebijakan sepertinya ini dulu pernah dilakukan dari Kementerian Agama dengan pemberian beasiswa penuh dan ternyata peminatnya cukup banyak. Pihak lembaga perlu melakukan affirmative action terhadap jurusan yang minim peminat dengan adanya kemudahan-kemudahan yang tidak melanggar aturan administrasi. Seperti penurunan grade UKT, diberikan 
program pemagangan yang lebih banyak, proporsi pengembangan kompetensi mahasiswa diperbanyak, dan pengembangan paket tour ilmiah mahasiswa berprestasi.

Dalam perspektif sosiologis, arah kebijakan pengembangan jurusan PMI sudah menunjukkan arah pengembangan yang jelas dengan dibuktikan dengan struktur kurikulumnya, mata kuliah jurusan, bidang peminatan, perangkat praktikumnya, hanya saja masih terbatas pada proses sosialisasi baik melalui media maupun kunjungan langsung. Program yang selama ini dilakukan seperti sosialisasi, program anjang sana, silaturrahmi ke ponpes, madrasah, pertemuan informal maupun non formal belum maksimal dilakukan. Disebabkan factor internal dan eksternal. faktor internal meliputi respon anggaran, fasilitas terbatas, SDM terbatas, sementara faktor eksternal meliputi perangkat ikatan alumni jurusan belum kuat kendati jurusan telah berusaha melakukan langkah-langkah kongrit dengan melibatkan beberapa instansi, ada yang dijadikan sebagai tenaga dosen, tempat magang dan praktikum. Misalnya, Dinas Sosial Propinsi, Yayasan Peduli Anak, Dasi, dll.

Dalam perspektif sosiologis sebenarnya arah kebijakan sudah tepat hanya saja ada poin-poin yang harus diperkuat lagi, misalnya kemampuan untuk melakukan bergaining bagaimana lulusan semakin bisa terserap di lembaga-lembaga mitra tersebut. Pihak jurusan dapat memfasilitasi lulusan untuk membangun komunikasi dengan alumni-alumni yang dipadang sukses bekerja, sehingga secara sosiologis mahasiswa PMl semakin percaya diri sebagai mahasiswa PMI. 
Menurut pengamatan peneliti, sebenarnya mahasiswa PMI tidak terlalu amat minim dari segi prestasi akademik, beberapa mahasiswa yang dipandang menonjol. Ada jebolan yang bakat kaligrafi, hafiz dan sebagai duta bahari. Potensi-potensi yang dimiliki jurusan PMI tidak kalah dengan potensi yang dimiliki oleh jurusan lain di lingkungan FDIK UIN Mataram. Tentu hal ini sebenarnya menjadi entry point dari jurusan PMI. Oleh karena itu, peran alumni menjadi penting dalam menjembatani mahasiswa meningkatkan daya tawar ketika mereka lulus dari jurusan PMI.

\section{Analisis Strategi Peningkatan Out Put Dan Mutu Lulusan Mahasiswa Jurusan PMI FDIK IAIN Mataram}

Berdasarkan pemetaan analisis strategis, hendaknya Jurusan PMI FDIK UIN Mataram harus menangkap peluang yang ada secara maksimal sambil memperbaiki kelemahan yang ada, misalnya mutu lulusan, proses perkuliahan, kelengkapan sarana dan prasarana yang masih belum memadai melalui strategi SO (memaksimalkan kekuatan untuk memanfaatkan peluang) dengan mengoptimalkan sumberdaya (resourch) khususnya Dosen S2 dan S3 sebagai pelaku perubahan belajar, peningkatan pola kemitraan dengan lembaga. strategi ST (memaksimalkan kekuatan untuk mengurangi ancaman) dengan peningkatan kinerja dan produktivitas dosen PMI, peningkatan kualitas layanan akademik dan non akademik, peningkatan daya saing mutu lulusan baik secara kualitas maupun kuantitas dalam menghadapi kompetisi global. Strategi WO 
(meminimalkan kelemahan untuk memanfaatkan peluang) melalui meningkatkan disiplin para dosen PMI, meningkatkan kemitraan dengan lembaga mitra dan memastikan ada lulusan yang dapat terserap, meningkatkan daya saing dalam marketing lulusan di dunia kerja khususnya yang terkait dengan kompetensi jurusan PMI. Sementara Strategi WT (meminimalkan kelemahan untuk mengurangi ancaman) dengan meningkatkan pemahaman dan persepsi masyarakat tentang keberadaan Jurusan PMI FDIK UIN Mataram melalui intensitas sosialisasi baik secara formal maupun non formal, meningkatkan kualitas lulusan barbasis kebutuhan masyarakat, meningkatkan kerja sama dengan industry kerja sesuai dengan bidang ke-PMI-an.

Untuk menentukan faktor-faktor kunci keberhasilan tersebut, maka jurusan PMI FDIK UIN Mataram harus menetapkan paling tidak beberapa strategi yang nantinya dapat dijadikan faktor-faktor kunci keberhasilannya. Oleh karena itu, ada beberapa strategi yang bisa dijalankan berikut ini: 1) Meningkatkan kualitas kompetensi lulusan yang sesuai dengan kebutuhan masyarakat. 2) Meningkatkan daya saing lulusan di dunia kerja, 3) Meningkatkan pemahaman dan persepsi masyarakat tentang keberadaan jurusan PMI FDIK UIN Mataram melalui program sosialisasi. 4) Meningkatkan fasilitas perkuliahan, 5) Peningkatan pola kemitraan dengan media kerja. 
Berdasarkan analisis SWOT maka disimpulkan ada tiga strategi umum yang harus dilaksanakan untuk peningkatan mutu lulusan empat tahun ke depan. Dari tiga strategi umum diimplementasikan, yaitu:

\section{1) Menumbuhkan Komitmen Tenaga Pendidik dan Kependidikan}

Jurusan PMI FDIK Mataram harus dipandang sebagai milik bersama, milik warga UIN Mataram. Sementara ini masih bersifat sporadis dan sektoral. Persoalan yang mendasar yang dirasakan adalah bagaimana menumbuhkan partisipasi civitas akademik untuk memberikan dukungan moral bahwa Jurusan PMI FDIK Mataram adalah institusi yang dibangun atas kebersamaan. Untuk itu diperlukan komitmen semua pihak untuk terus melakukan terobosan dan sosialisasi kepada masyarakat luas bahwa Jurusan PMI FDIK Mataram layak dikembangkan dan keberadaannya dibutuhkan di masyarakat. Artinya, setiap orang yang terikat dengan komitmen pengembangan kampus ini memiliki obsesi mengembangkan diri dan lingkungannya yang tidak mengenal berhenti dan pembatasan-pembatasan apa saja.

Persoalan kemudian adalah bagaimana mengembangkan partisipasi dan mengembangkan kualitas tenaga manusia atau human resourcesnya ini. Jawaban yang dapat diajukan sementara ini ialah melakukan langkah-langkah sebagai berikut : a) melakukan dialog terbuka dari hati ke hati secara terus menerus, b) menugaskan kepada mereka melakukan studi banding ke berbagai perguruan tinggi yang 
sudah maju, c) menyelenggarakan kuliah tamu dari para expert, dan d) memberikan peran-peran sesuai dengan minat atau kesenangan masingmasing dosen yang ada.

\section{2) Peningkatan Manajerial Marketing PMI}

Inti manajemen adalah kemampuan mengelola, menggerakkan dan memanfaatkan seluruh kekuatan yang dimiliki secara maksimal untuk meningkat kualitas lulusan Jurusan PMI FDIK UIN Mataram. Pengembangan dan penguatan manajemen dilakukan melalui pendekatan holistik, yaitu yang dapat menyentuh berbagai aspek, yang meliputi : a) Pengembangan aspek material, moral spiritual, dan emosional. Pengembangan aspek material berupa peningkatan kesejahteraan dan kualitas hidup; aspek moral spiritual dikembangkan melalui kegiatan pengalaman keagamaan dengan cara melakukan shalat berjamaah di Masjid, pembudayaan puasa sunnah Senin-Kamis, spiritual contemplation, khotman al-Qur'an dan sebagainya, melakukan aspek emosional dikembangkan melalui sentuhan individu maupun kelompok, b) Pengembangan profesional. Pengembangan ini berupaya meningkatkan kadar keilmuan, keahlian dan ketrampilan sumber daya manusia yang dimiliki, c) Pengembangan program pendidikan. Pengembangan ini berupaya membuka progran-program pendidikan yang responsif sesuai tuntutan kebutuhan dan perkembangan masyarakat, d) Pengembangan organisasi/kelembagaan. Pengembangan 
ini berupaya memberikan pelayanan yang mudah, ramah, cepat dan meninggalkan kesan birokrasi yang berbelit-belit, e) Pengembangan silaturrahmi. Pengembangan ini berupaya menumbuh kembangkan silaturrahim antara warga besar civitas akademik, orang tua/wali mahasiswa dan masyarakat yang terlibat dalam pengembangan Jurusan PMI FDIK UIN Mataram untuk berkomitmen mencapai tujuan, f) Pengembangan kerjasama. Pengembangan ini berupaya untuk membangun kerjasama dalam peningkatan kualitas SDM, program pendidikan, penelitian, dan pengabdian masyarakat.

\section{3) Membangun Hubungan Kemitraan}

Selama ini, lembaga pendidikan besar dan kuat karena berbagai upaya dan terobosan yang dilakukan. Lembaga manapun dalam era global yang kompetetif saat ini, membangun jejaring (networking) dengan berbagai pihak menjadi suatu keniscayaan dan bahkan merupkan salah satu pilar kekuatan lembaga yang harus dilakukan. Dalam hal ini, Jurusan PMI FDIK UIN Mataram telah berusaha ke arah tersebut dengan menggandeng lembaga-lembaga yang memiliki relevansi dengan konsentrasi yang dikembangkan, seperti Dinas Sosial dan Tenaga Kerja Provinsi NTB, Lapas Anak, Yayasan Peduli Anak, NGO, BNN, Pantai Sosial NTB, Panti Budi Rini Mataram. 


\section{Penutup}

Masyarakat mempersepsikan keberadaan Jurusan PMI FDIK UIN Mataram sebagai jurusan yang asing, tidak tahu arah dan tujuannya. Hal ini sebagai akibat dari minimnya intesitas interaksi antara lembaga dengan masyarakat. Media komunikasi yang ada masih belum berfungsi maksimal sebagai jembatan mempromosikan lembaga ke tengah masyarakat. Promosi dan sosialisasi masih dominan melalui proses formalis dan akademis, padahal proses sosialisasi dengan pendekatan kultural lebih menjanjikan. Arah kebijakan melalui dua yakni kebijakan akademik dan sosiologis. Kebijakan akademik diarahkan kepada penguatan struktur dan perangkat akademik (kurikulum, perangkat pendukung perkuliahan) dan kebijakan sosiologis lebih menitikberatkan pada penguatan pola kerja sama atau kemitraan baik kepada para alumni dan kepada lembaga mitra. Strategi yang dilakukan melalui peningkatan SDM, memperkuat kemitraan, penguatan program sosialisasi dan program layanan akademik 


\section{Daftar Pustaka}

AL-Mutairi, Abdullah \& Saeid, Muna, Factors Affecting Students' Choice for MBA Program in Kuwait Universities, International Journal of Business and Management (Vol. 11, No. 3; 2016)

Wahab, Abdul, Solichin, Pengantar Analisis Kebijakan Publik (Malang:UMM Press, $2011)$

Jurusan Pengembangan Masyarakat Islam (PMI) Fakultas Dakwah dan Komunikasi IAIN Mataram beroperasi berdasarkan SK Dirjen Pembinaan Kelembagaan Islam Departemen Agama RI Nomor: E/123/2001.

Surat Keputusan Perpanjangan Izin Penyelenggaraan dari Direktur Jendral Pendidikan Tinggi Islam Nomor: Dj. I/ 221 / 2007 tanggal 29 Mei 2007. Dan dengan usaha keras untuk meningkatkan status jurusan maka jurusan PMI kemudian terakreditasi oleh Badan Akreditasi Nasional-Perguruan Tinggi (BAN-PT) nomor: 002/BAN-PT/Ak.XIII/S1/IV/2010, tertanggal 30 April 2010 dengan nilai B. Status akreditasi ini berlaku selama 5 (Lima) tahun (20102015). Buku Pendoman Akademik FDK IAIN Mataram Tahun 2015

Porter, Michael E, Competitive Strategy: Techniques for Analyzing Industries an Competitors (New York: The Free Press, 1980)

Ariani, Wahyu, Dorothea, "TQM dalam Sektor Pendidikan", Jurnal Modus (FE-UAJY, 1998)

Greech, Bill, Lima Pilar Manajemen Mutu Terpadu (Total Quality Management (Jakarta: Binarupa Aksara, 1996)

Kawiana, IGP, Manajemen Mutu Terpadu serta Kaitannya Dengan Perilaku Produktif Karyawan, Diakses 21 Februari 2017 dari https://geogle.com

Muchammadun, "Transformasi IAIN ke UIN: Tinjauan Psikologi Sosial pada Jurusan PMI FDK IAIN Mataram", Jurnal Tasammuh (Vol. 12. No 1. Desember 2014) 


\section{Petunjuk Penulisan}

Tasâmuh menerima tulisan dalam bentuk artikel dan laporan penelitian, baik yang menggunakan bahasa Indonesia, Inggris, maupun Arab, dengan ketentuan sebagai berikut:

1. Tulisan tersebut belum pernah diterbitkan atau dipublikasikan dalam suatu jurnal berkala atau buku.

2. Topik tulisan berkisar pada kajian-kajian yang berkaitan dengan ilmu dakwah dan Komunikasi.

3. Judul tulisan maksimal 14 kata.

4. Semua tulisan harus menyertakan abstrak (100-150 kata) dan kata kunci (3-7 kata).

5. Jumlah halaman antara 15-20 nomor halaman dengan ukuran kwarto spasi ganda dengan menggunakan jenis huruf Futura $\mathrm{Lt} \mathrm{B} \dagger$ dan besar hurup 12 pt.

6. Setiap kata Arab yang belum resmi terbakukan dalam bahasa Indonesia ditulis mengikuti pedoman transliterasi yang ditetapkan dan cara penulisannya dimiringkan (italic), hal ini juga berlaku untuk kata-kata asing yang lain (seperti bahasa Inggris dan bahasa Daerah) dan cara penulisannya dimiringkan (italic),

7. Transliterasi tidak berlaku untuk nama orang, tempat, institusi, dan sejenisnya.

8. Penulis menyerahkan file beserta print out naskahnya.

9. Semua tulisan menggunakan referensi model footnote dengan teknik penulisan sebagai berikut: Nama Penulis, Judul Buku Yang Ditulis Miring (Kota Penerbit: Nama Penerbit, Tahun Terbit), Nomor Halaman. Sebagai contoh:

a. Buku atau Kitab:

- John Lewis Coser, The Function of Social Conflict (New York: Free Press, 1969), 125. 
- Sofian Effendi, Membangun Martabat Manusia Dalam Perspektif Islam (Yogakarta: UGM Press, 2005), 24.

- Ibnu Jarir al-Thabari, Jami' al-Bayan, Jilid 9 (Beirut: Dar alKutub Ilmiyah, 1992), 67.

b. Buku Terjemahan:

David Hill, Pengembangan dan Pemberdayaan Masyarakat, ter. Adam Hulaimi, Jilid 2 (Jakarta: Pustaka Pelajar, 1997), 127.

c. Artikel dalam Buku atau Ensiklopedi:

- Nurcholis Majid, "Cendekiawan dan Penguatan Civil Society di Indonesia" dalam Peran Cendekiawan Muslim Dalam Menegakkan Hak Politik Civil Society, ed. Tim Editor Masika (Jogjakarta: Bintang Budaya, 1996), 124.

- D.S. Adam, "Theology," Encyclopedia of Religion and Ethics, ed. James Hastings, Jilid 4 (New York: Charles Scribner's Sons, tt), 293.

d. Artikel dalam Jurnal:

Faisal Ismail, "On Developing Liberation Theology in Islam," dalam Jurnal Gazwatul Fikri, Vol. 9 No. 2 (Yogyakarta: Fakultas Dakwah UIN Sunan Kalijaga, Desember 1999), 165.

e. Artikel dalam Media Massa:

Fawaizul Umam, "Quo Vadis Kebebasan Beragama di Indonesia", dalam Koran KOMPAS, Edisi 30 Maret 2001, 4.

f. Kitab Suci:

QS. al-Qashash (28): 5. Perjanjian Baru, Yoh ( 20): 31.

g. Bila mengutip ulang referensi yang sama secara berurut, maka cukup tulis: Ibid. Jika halamannya berbeda, cukup tambahkan nomor halamannya: Ibid., 14.

h. Bila referensi terkutip ulang berselang oleh satu atau lebih referensi berbeda, maka cukup tulis last name pengarang berikut satu kata awal judul dari referensi dimaksud. Misalnya, Zahrah, Ushûl..., 35. 
10. Selain mencantumkan footnote, penulis juga harus mencantumkan DAFTAR PUSTAKA dengan aturan penulisan diurutkan secara alfabetis. Nama penulis diketik dengan mendahulukan nama marga atau nama akhir jika nama penulis terdiri dari 2 kata atau lebih, judul buku atau nama jurnal maupun nama media massa ditulis miring (Kota Penerbit: Lembaga Penerbit, Tahun Terbit) tanpa diakhiri tanda titik.

Contoh:

a. Buku: Nasution, Harun, Perkembangan Pemikiran Cendikiawan Muslim Indonesia (Jakarta: Dunia Ilmu, 1998)

b. Jurnal: Ismail, Faisal, "On Developing Liberation Theology in Islam," dalam Jurnal Gazwatul Fikri, Vol. 9 No.2 (Yogyakarta: Fakultas Dakwah UIN Sunan Kalijaga, Desember 1999)

c. Media massa: Umam, Fawaizul, "Quo Vadis Kebebasan Beragama di Indonesia", dalam Koran KOMPAS, Edisi 30 Maret 2001

d. Makalah: Akbar, Muhammad, "Membangun Paradigma Baru Fakultas Dakwah", dalam Makalah Seminar Pengembangan Fakultas Dakwah di Indonesia, Mataram, 3 Maret 2004 